\title{
MEDICATION WHICH MAY INHIBIT CARDIOVASCULAR REACTIVITY TO STRESS*
}

\author{
P Charlebois, B SC, B A, M D,$\uparrow$ ANd P Gledhill, B pharm
}

THERE HAS BEEN such a tremendous pioliferation of new drugs, pharmaceutical compounds, brand names, and trade names that it is impossible for the wellinformed physician to be fully cognizant of all their constituents and properties Some of the compounds may produce their desired effect by selatively innocuous means However, some achieve their desired effect by influencing very profoundly a basic body mechanism This effect ol ten becomes apparent only when the patient is under severe stress, as during a surgical operation

The drugs which concern the anaesthetst may cause electrolyte imbalance, interfere with an enzyme system, or reduce the body's production of basic substances One of the distressing side-effects is a reduced vascular reactivity to catecholamines If effective, some of these drugs cause a suppression of the adrenal response and a relative uncrease 110 parasympathetic activity Under these circumstances anaesthetic agents may produce a greater than expected cardiovascular depression This may be manifested as severe hypotension with bradycardia The sympathoadrenal systen serves as a compensatory mechanism to ensure adequate venous return and cardiac output particularly during intermittent positive pressure ventlation and to offset the cardiovascular depression of anaesthetic drugs

The Ephedine Response Test is a means of evaluatung the status of a patient's sympathoadrenal system because it demonstrates the ability of the cardiovascular system to react to stress Ephedrine is given intravenously and causes a release of catecholamines or vasopressor substunces from their storage sites in the body This enables us to determine the vascular reactivity to and avallability of catecholamines in the body

The Ephedrne Response Test cornsists of two parts An intravenous injection of $10 \mathrm{mg}$ of ephedrme in $1 \mathrm{cc}$ of solution is first made If there is not an adequate response by the patient a second dose of $5 \mathrm{mg}$ of ephedrine is given intravenously If after $15 \mathrm{mg}$ of ephedrine an adequate response does not occur, then spinal, epidural, and general anaesthetics are contraindicated $\mathbb{B y}$ an adequate response we mean an increase in systolic blood pressure of over $20 \mathrm{~mm} \mathrm{Hg}$ and an increase in the heart rate of at least 10 beats per minute If this response does not occur, it will indicate that there is a depletion of catecholammes in the body and that the patient's cardiovascular system has a very limited ability to compensate for stress

"This artucle is presented under the auspices of the Scarborough Medical Research Foundation

\$Department of Anaesthesid, Scarborough General Hospital

tChief Pharmacist, Scarborough General Hospital, Scarborough, Ontano 
In any case, if the treatment for hypertension has not been successful, there will have been no effect on the patient's catecholamine stores and there will be no necessity to perform the Ephedrine Response Test.

The Rauwolfia alkaloids are very popular in the treatment of hypertension The cardiovascular effects of Rauwolfia alkaloids consist of a reduction of arterial blood pressure and a slowing of the heart rate This may result from a central depression of the vasomotor system because centrally mediated cardiovascular reflexes such as the caroud sinus baroreflex are inhibited This decreases the body's ability to compensate for blood loss and position change The Rauwolfia alkaloıds are believed to deplete the catecholamine (vasopressor) stores centrally from the hypothalamic centres and peripherally from the postganglionic nerve endings With Rauwolfia the phosphorylase activity of the myocardium, which is important in the production of energy for the maintenance of myocardial contractility, is decreased

In man the cardıovascular actions of Rauwolfia become apparent after 3-4 days of continuous therapy and do not become maximal for several weeks Goodman and Gillman state that the hypotensive action of Rauwolfia is more prominent when it is combined with one or more of the other antilnypertensive agents The Rauwolfia alkaloids themselves disappear rapidly from the body, but the catecholamine stores such as epınephrine and norepinephrine are replenıshed gradually over a 10-14 day period It is for this reason that a patient should not be anaesthetzed for fourteen days after his last dose of Rauwolfa alkalord Theoretically a Rauwolfia-induced hypotension can be corrected by supplying the necessary amines, $1 \mathrm{e}$, norepinephrine, methoxamine, or phenylephine

The following is a list of current pieparations contar|ıng Rauwolfia alkaloids

\section{Rauwolfia Alkaloids}

\begin{tabular}{|c|c|c|}
\hline Ingredient & Trade name & Company \\
\hline Rauwolfia & $\begin{array}{l}\text { Raudixin } \\
\text { Rautractyl } \\
\text { Rautrax } \\
\text { Raufia } \\
\text { Raullord } \\
\text { Raullord \& Venlord } \\
\text { Verilord }\end{array}$ & $\begin{array}{l}\text { Squibb } \\
\text { Squibb } \\
\text { Squibb } \\
\text { P Nancy } \\
\text { Riker } \\
\text { Riker } \\
\text { Riker }\end{array}$ \\
\hline Resperine & $\begin{array}{l}\text { Serpasıl } \\
\text { Serp } 1 s 1 \text {-Esıd } 11 x\end{array}$ & $\begin{array}{l}\text { Cuba } \\
\text { Crba }\end{array}$ \\
\hline $\begin{array}{l}\text { Active principle } \\
\text { in Rauwolfia }\end{array}$ & $\begin{array}{l}\text { Serpasıl-Apresolne } \\
\text { Ser-ap-es } \\
\text { Serpatiln } \\
\text { Diupres } \\
\text { Hydiopies } \\
\text { Alserin } \\
\text { Serfin } \\
\text { Bitab \#33 } \\
\text { Bitab \#44 } \\
\text { Bitab \#66 } \\
\text { Bitab \#506 (Tened) } \\
\text { Butiserpine }\end{array}$ & $\begin{array}{l}\text { Ciba } \\
\text { Ciba } \\
\text { Ciba } \\
\text { Merck } \\
\text { Merck } \\
\text { Frosst } \\
\text { P' D Co } \\
\text { Canada Pharmacal } \\
\text { Canada Pharmacal } \\
\text { Canada Pharmacal } \\
\text { Canada Pharmacal } \\
\text { McNeill }\end{array}$ \\
\hline
\end{tabular}




$\begin{array}{lll}\begin{array}{l}\text { Ingredient } \\ \text { Resperpidine }\end{array} & \text { Trade name } & \text { Company } \\ \text { or } & \text { Decaserpyl } & \\ \text { Deserpidine } & \text { Harmonyl } N & \text { Roussel } \\ & & \text { Abbott }\end{array}$

\section{Guanethidine}

The drug Guanethidme seems to have the same pharmacologic actions as Bretylum Tosylate These two drugs are enjoying limited popularity as antihypertensives and sedatives Their action appears to be an inhibition of the peripheral release of catecholamines from the postganghonic sympathetic nerve endings They do not appear to affect the catecholamine concentration of the adrenal medulla or the brain However, they are belleved to decrease the norepinephrine content of heart muscle The action of Guanethidine and possibly Bretylium Tosylate persists for seven days after the last dose of medication Therefore, it would be unwise to give a patient an anaesthetic until he has had at least a week to recover from the effects of the drug However, theoretically a hypotensive episode due to this medication could be corrected by the giving of perrpherally acting vasopressors such as methoxamine, norepinephrine, or phenylephrne

$\begin{array}{lll}\text { Ingredient } & \text { Trade naine } & \text { Company } \\ \text { Guanethidine } & \text { Ismelin } & \mathrm{Cba} \\ & \text { Ismeln-Esıdrix } & \mathrm{Cba} \\ \text { Bretylium Tosylate } & \text { Darenthin } & \mathrm{B} \mathrm{W}\end{array}$

\section{Monoamine Oxidase Inhibıtors}

Monoamine oxidase is an enzyme conriected with the breakdown of serotonin, norepinephnne, and epınephrine This erizyme causes an increase in the ganghonic norepinephrine content This paradoxically causes hypotension Apparently an increased concentration of these amines/ decreases ganglionic transmission and decreases the body's ability to compensate for hypovolaemia and hypotension

Monoamine oxidase inhibitors are used to treat depressed patients These drugs are termed psychic energizers because they increase the concentration of the amines serotonin and norepinephrne in the brain The effect of these antidepressants lasts for days to weeks after their withdrawal The monoamine oxidase inhibitors potentiate the effect of many drugs, for example (1) morphine, (2) barbiturates, (3) anaesthetic agents, (4) atropine, (5) gangliomic blocking agents

As yet there are few, if any, reports of adverse effects by monoamine oxıdase inhibitors in anaesthetic journals However, patients on these drugs should be treated with even greater caution Monoamine oxidase inhibitors include the amphetamines and their analogues

\begin{tabular}{|c|c|c|c|}
\hline Ingredient & Trade name & & Company \\
\hline $\begin{array}{l}\text { Amphetamine and } \\
\text { derivative }\end{array}$ & $\begin{array}{l}\text { Ambar } \\
\text { Bitab \#33 } \\
\text { Bitab \#77 }\end{array}$ & $\begin{array}{l}\text { Mild } \\
\text { effect }\end{array}$ & $\begin{array}{l}\text { Robins } \\
\text { Canada Pharmacal } \\
\text { Canada Pharmacal }\end{array}$ \\
\hline
\end{tabular}


Ingredient

Methylphenidate

Amitriptyline

Isocarboxazid

Nialamide

Phenelzine

Tranylcypromine

Tranylcypromine with stelazine

Imipramine

Imipramine with sparine
Trade name

$\begin{aligned} & \text { Desoxyn } \\ & \text { Dexamyl } \\ & \text { Dexadrine } \\ & \text { Methedrine }\end{aligned}$
Ritalin
Elavil
Marplan
Niamıd
Nardıl
Parnate
Parsteln
Tofranıl
Tofranazıne

Company

Abbott

S K F.

S K F

$B \& W$.

Ciba

Merck

Roche

Pfizer

Warner Chilcott

S K F

S K F

Geigy

Gergy

A more recent product is
Pargline
Eutonyl
Abbott

This is an anthypertensive agent, with the antidepressant properties of monamine oxidase inhibitors

\section{Duretıcs Especially Thazıde Dervatwes}

These cause a decreased vascular reactivity to catecholamines and other vasopressors, an effect which is related to sodium depletion in the peripheral vascular wall They can also cause a low serum potassium level which enhances digitalis toxicity Because of this, an anaesthetic should not be given to patients until four days after they have received their last dose of Thiazide medication

These agents will potentiate the hypotensive effects of preganglionic blockades of spinal and epıdural anaesthesia and the ganglionic blockade of $d$-tubocurare Hypotension caused by these drugs is best treated by a plasma volume expander

\begin{tabular}{|c|c|c|}
\hline Ingredient & Trade name & Company \\
\hline Acetazolamide & Diamox & Lederle \\
\hline Chlorothiazide & Diunl & Merck \\
\hline $\begin{array}{l}\text { Chlorothiazide } \\
\text { with reserpine }\end{array}$ & Diupres & Merck \\
\hline Hydrochlorothiazide & $\begin{array}{l}\text { Hydrodiurl, Esidrux } \\
\text { Oretic }\end{array}$ & Merck, Crba and Abbott \\
\hline $\begin{array}{l}\text { Hydrochlorothiazide } \\
\text { with reserpine } \\
\text { Hydrochlorothiazide }\end{array}$ & Hydropres & Merck \\
\hline with reserpine & Serpasıl-Esıdrux & Clba \\
\hline Hydrochlorothiazide & Ser-ap-es & Ciba \\
\hline Hydroflumethiazıde & Saluron & Bristol \\
\hline Bendroflumethrazide & Naturetun & Squibb \\
\hline Truchloromethrazıde & Naqua & Schering \\
\hline Polythıazıde & Renese & Roerig \\
\hline Methylclothrazide & Duretic & Abbott \\
\hline Benzthıazıde & Exna & Robins \\
\hline
\end{tabular}


Non Thrazide products with similar actions are

$\begin{array}{lll}\text { Chlorthalidone } & \text { Hygroton } & \text { Geigy } \\ \text { Spironolactone } & \text { Aldactone } & \text { Searle }\end{array}$

\section{Decarboxylase Inhubutors}

The drug Aldomet TN inhibits the metabolic decarboxylation of dopamine, a precursor of norepinephrine and serotonin This drug is largely excreted by the kidneys Therefore, patients with impaired renal function will respond to smaller doses Aldomet ( TN) has a short duration of action, a withdrawal is followed by a prompt return to previous blood pressure levels within 48 hours

As this drug is relatively new, its impact upon the anaesthetized patient has not been published However, patients on this medication should be tieated with much caution

$\begin{array}{lll}\text { Drug } & \text { Trade name } & \text { Company } \\ \text { Methyldopa } & \text { Aldomet } & \text { Merck }\end{array}$

\section{RÉSUMÉ}

Il y a eu une telle avalanche de nouveaux médicaments, de produits pharmaceutıques, de marques de commerce quill est impossıble que le médecin-même bien renseigné-soit au courant de la composition et des propriétés de tous ces pioduits Quelques-uns de ces composés peuvent produrre l'eflet désiré sans inconvénient D'autres cependant produsent leur effet en affectant certains mécanismes impoitants du corps humain Souvent cet effet ne se fait sentır qu'à l'occasion d'un stress sérneux, $\mathrm{p}$ ex une operation chirurgicale

Les produits qui intéressent l'anesthésıe peuvent produire des troubles de l'équilıbre électrolytıque, gêner un système d'enzymes, ou dımınuer la productıon de substances de base Un des effets secondarres assez alarmant est une dimmution de la réaction vasculaire aux catécholamines Sils sont efficaces, quelquesuns de ces produits abolissent la réponse surrénalienne et augmentent l'activité parasympathique Dans ces conditions, les agents anesthésıques peuvent produrre une dépression cardı-vascularre plus importante que celle qu'on avait prévue Cecı se manifeste par une hypotension gi ave avec bradycardıe Le système sympathico-surrénalien agit comme mécanısme compensateur pour assurer un retour veineux et un débit cardiaque suffisants durant les manoeuvres de ventilation pai pression positive intermittente, 1 rémédıe aussı à la dépression cardı-vasculaire produite par les agents anesthésiques

Les auteurs ont décrit brièvement l'acion pharmacologique des alcaloides de la Rauwolfia, de la Guanéthidine, des inhibiteurs de la Mono-amine oxydase et de la décarboxylase, des dérivés de la Thiazıne, et ils ont fourni une liste des médicaments composés à base de ces substances, du nom sous lesquels ils sont mis sur le marché et du nom du manufacturner 